medRxiv preprint doi: https://doi.org/10.1101/2021.07.19.21260782; this version posted July 28, 2021. The copyright holder for this preprint

(which was not certified by peer review) is the author/funder, who has granted medRxiv a license to display the preprint in perpetuity.

It is made available under a CC-BY-NC-ND 4.0 International license .

\title{
Does COVID-19 vaccination improve mental health? A difference-in-difference analysis of the Understanding Coronavirus in America study
}

Jonathan Koltai ${ }^{1}$, PhD, Julia Raifman ${ }^{2}, \mathrm{ScD}$, Jacob Bor ${ }^{3}, \mathrm{ScD}$, Martin McKee ${ }^{4}$, MD, DSc, and David Stuckler, $\mathrm{PhD}^{5}$

\begin{abstract}
Background: Mental health problems increased during the COVID-19 pandemic. Knowledge that one is less at risk after being vaccinated may alleviate distress, but this hypothesis remains unexplored. Here we test whether psychological distress declined in those vaccinated against COVID-19 in the US and whether changes in perceived risk mediated any association. Methods: A nationally-representative cohort of U.S. adults $(\mathrm{N}=5,792)$ in the Understanding America Study were interviewed every two weeks from March 2020 to June 2021 (28 waves). Difference-indifference regression tested whether getting vaccinated reduced distress (PHQ-4 scores), with mediation analysis used to identify potential mechanisms, including perceived risks of infection, hospitalization, and death. Results: Vaccination was associated with a 0.09 decline in distress scores (95\% CI: -0.15 to -0.04$)$ (0-12 scale), a 5.7\% relative decrease compared to mean scores in the wave prior to vaccination. Vaccination was also associated with an 8.44 percentage point reduction in perceived risk of infection (95\% CI: $-9.15 \%$ to $-7.73 \%)$, a 7.44 -point reduction in perceived risk of hospitalization ( $95 \% \mathrm{CI}:-8.07 \%$ to $-6.82 \%$ ), and a 5.03-point reduction in perceived risk of death (95\% CI: $-5.57 \%$ to $-4.49 \%$ ). Adjusting for risk perceptions decreased the vaccination-distress association by two-thirds. Event study models suggest vaccinated and never vaccinated respondents followed similar PHQ-4 trends pre-vaccination, diverging significantly post-vaccination. Analyses were robust to individual and wave fixed effects, time-varying controls, and several alternative modelling strategies. Results were similar across sociodemographic groups. Conclusion: Receiving a COVID-19 vaccination was associated with declines in distress and perceived risks of infection, hospitalization, and death. Vaccination campaigns could promote these additional benefits of being vaccinated.
\end{abstract}

1. Assistant Professor, Department of Sociology, University of New Hampshire, Durham, US 2. Assistant Professor, Department of Health Law, Policy, and Management, Boston University School of Public Health, Boston, Massachusetts

3. Assistant Professor, Department of Global Health, Boston University School of Public Health, Boston, Massachusetts

4. Full Professor, Centre for Global Chronic Conditions, London School of Hygiene and Tropical Medicine, London, UK

5. Full Professor, Dondena Centre for Research on Social Dynamics and Public Policy, Bocconi University, Milan, Italy. 
medRxiv preprint doi: https://doi.org/10.1101/2021.07.19.21260782; this version posted July 28, 2021. The copyright holder for this preprint (which was not certified by peer review) is the author/funder, who has granted medRxiv a license to display the preprint in perpetuity.

\section{Introduction}

On May $13^{\text {th }} 2020$, the United Nations warned that although COVID was primarily an infectious disease, it was also sowing the "seeds of a major mental health crisis"(1). Surveys in the United States reveal elevated levels of psychological distress, anxiety, and suicidal ideation since the onset of the pandemic.(2-6) Several factors have contributed to these findings, including loss of income and work, food insecurity, social isolation, additional care-giving burdens, substance use, and racialized discrimination.(7-18) Personal experience of COVID-related illness and death or hospitalization of a loved one may also contribute. $(19,20)$ One recent study points to anticipatory fears, with perceived risk of infection and mortality explaining $20.7 \%$ of the increased distress between March and June 2020.(21)

High rates of vaccination are crucial to prevent the spread of COVID-19 and its many consequences, including worsening mental health. Yet, as of July $4^{\text {th }}$, only $67.1 \%$ percent of US adults have been vaccinated,(22) falling short of President Biden's target of $70 \%$ by the same date, and daily vaccination rates have fallen sharply.(23) While side effects and safety top the list of concerns of those not vaccinated, lack of information and access remain barriers for vulnerable individuals, particularly people of color.(24) Many people of color who are not yet vaccinated express vaccine hesitancy but also high perceived risk from COVID-19 infection.(25) Meanwhile, although the poor and those facing food and housing insecurity are less likely to be vaccinated, many, especially those with children, want a vaccine.(26)

Are there individual and social benefits of vaccination beyond preventing infection? One hypothesis, so far unexplored, is whether vaccination improves mental health by reducing anticipatory fears of infection, hospitalization, and death. We use a difference-in-difference method with nationally-representative longitudinal data to test whether vaccination for COVID- 
medRxiv preprint doi: https://doi.org/10.1101/2021.07.19.21260782; this version posted July 28, 2021. The copyright holder for this preprint (which was not certified by peer review) is the author/funder, who has granted medRxiv a license to display the preprint in perpetuity.

It is made available under a CC-BY-NC-ND 4.0 International license .

19 reduces psychological distress and, if so, whether lower perceived risk mediates this association.

\section{Study Design and Methods}

\section{Data Source}

We used data from the Understanding Coronavirus in America (UCA) study,(27) an extension of an internet-based, nationally representative longitudinal survey.

We examined 28 survey waves, between March 2020 and June, 2021. We restricted the sample to participants in at least 2 survey waves with non-missing values for our exposure, outcome, and covariates and excluded person-period observations in which respondents indicated being unsure of their vaccination status. Our primary analytic sample included 5,792 individuals. Table 1A in the supplement shows dates of each study wave.

\section{Exposure}

Our primary exposure was vaccination status, coded as 1 beginning in the first wave in which the respondent answered yes to the question "Have you gotten vaccinated for the coronavirus?" and imputed as 1 thereafter. It was coded as 0 for "No" and imputed as 0 in each period prior to Wave 21 (December 23, 2020 to January 18, 2021), the first time this question was asked.

\section{Outcome}

Psychological distress was assessed using the Patient Health Questionnaire (PHQ-4) developed by Kroenke et al.(28), and validated by Lowe et al.(29) The scale consists of the first two items from the PHQ-9 and the Generalized Anxiety Disorder-7 (GAD-7) which assess core criteria for depressive (e.g. "Little interest or pleasure in doing things") and anxiety disorders (e.g. "Feeling nervous, anxious or on edge") respectively. Participants report how often they have been 
medRxiv preprint doi: https://doi.org/10.1101/2021.07.19.21260782; this version posted July 28, 2021. The copyright holder for this preprint (which was not certified by peer review) is the author/funder, who has granted medRxiv a license to display the preprint in perpetuity.

It is made available under a CC-BY-NC-ND 4.0 International license .

bothered by these problems over the last 2 weeks on a four-point scale scored as 0 ("not at all"), 1 ("several days"), 2 ("more than half the days"), or 3 ("nearly every day"). Scores on the scale range from 0 to 12 with higher scores indicating greater distress. Our main analyses use total PHQ-4 scores. We also use a variable for severe distress in supplementary analyses, coded 1 if PHQ-4 scores 9 or above and 0 for those below.(28)

\section{Mediators}

Participants were asked "On a scale from 0 to $100 \%$, what is the chance that you will get the coronavirus in the next three months?" and then "If you do get the coronavirus, what is the percent chance you will be hospitalized (spend at least one night in the hospital) from it?" Finally, perceived infection-fatality risk was assessed by asking "If you do get infected with the coronavirus, what is the chance you will die from it?", with responses also recorded as 0 to $100 \%$

\section{Covariates}

In our main analyses we included individual fixed effects (separate indicators for each person) to adjust for all time-invariant respondent characteristics. We included survey wave fixed effects (separate indicators for each wave) to adjust for national secular trends in mental health. We also adjusted for several time-varying, self-reported covariates: receiving Supplemental Nutrition Assistance Program (SNAP) benefits in the month prior to the survey, receiving unemployment insurance past 14 days, and employment status at the time of the survey.

\section{Statistical Analysis}

We first described the demographic characteristics of the sample by vaccination status, which are shown in Table 2A of the supplement. We then use graphical methods to visualize unadjusted 
medRxiv preprint doi: https://doi.org/10.1101/2021.07.19.21260782; this version posted July 28, 2021. The copyright holder for this preprint (which was not certified by peer review) is the author/funder, who has granted medRxiv a license to display the preprint in perpetuity. It is made available under a CC-BY-NC-ND 4.0 International license .

temporal trends in psychological distress scores (Figure 1A) and perceived risk factors (Figure 2A) in the supplementary appendix.

Next, we use two-way fixed effects models to assess the association between receiving a COVID-19 vaccination and changes in mental health. These models take the form:

$$
\gamma_{i t}=\alpha+\text { Vaccinated }_{i t}+\mu_{i}+W_{t}+X_{i t}+\varepsilon_{i t}
$$

Where $\gamma_{i t}$ denotes psychological distress for individual i at wave t. $\mu_{i}$ and $W_{t}$ are individual and wave fixed effects respectively, $X_{i t}$ represents time-varying controls. Vaccinated $_{i t}$ is an indicator variable that switches to 1 in first wave in which the respondent answered yes to the question "Have you gotten vaccinated for the coronavirus?" and remains as 1 thereafter.

To assess how the outcomes of interested changed over time before and after vaccination, we estimated so-called "event study" models, wherein Vaccinated $_{i t}$ was replaced with dummy variables indicating the number of periods prior to or following a respondent's first report of COVID-19 vaccination. $(30,31)$ We binned dummy variables for lags at 4 or more waves (8 or more weeks) post-vaccination, reflecting the $99^{\text {th }}$ percentile of the distribution of observations in our sample. The event study specification provides two important pieces of information not observable in the single-coefficient two-way fixed effects model.(32) First, that model assumes that distress would have continued along the same trajectory in those who were or were not vaccinated. While this cannot be tested explicitly, including all event leads reveals in the pretreatment period when coefficients for leads (pre-vaccination) differing significantly from zero would suggest violation of the parallel trends assumption. By contrast, non-zero coefficients for lags (post-vaccination) indicate statistically significant treatment effects. Second, the lags make 
medRxiv preprint doi: https://doi.org/10.1101/2021.07.19.21260782; this version posted July 28, 2021. The copyright holder for this preprint (which was not certified by peer review) is the author/funder, who has granted medRxiv a license to display the preprint in perpetuity.

It is made available under a CC-BY-NC-ND 4.0 International license .

it possible to see whether the effects grow or shrink over time, and whether they persist. For all analyses, we clustered standard errors by individuals to account for serial correlation.

We conducted several sensitivity checks to test whether the effects of vaccination vary by demographic subgroups, and whether they are robust to alternative modelling strategies.

\section{Results}

Table $2 \mathrm{~A}$ in the supplement shows a gradient in vaccination status by age, income, and education, with higher rates of vaccination observed among older respondents and those at the higher end of the socioeconomic status spectrum. Among self-reported race categories, Asians had the highest rates of vaccination (69\%), followed by Hawaiian/Pacific Islander (59\%), Whites (57\%), mixed race respondents (49\%), Black respondents (48\%), and American Indian and Alaska Natives (38\%). Males had slightly higher rates of vaccination (59\%) compared to females (54\%) in our sample. Married individuals living with partners had the highest rates of vaccination (61\%) among marital status groups, while separated individuals had the lowest $(36 \%)$.

Figure 1A shows the secular trends in distress scores for never vaccinated respondents and respondents who became vaccinated during our study period. Distress scores increase for both groups at the outset of the pandemic, peaking in Wave 2 (4/1/2020 to 4/27/2020), then decline steadily until Wave 7 (6/10/2020 to 7/6/2020). Notwithstanding some fluctuations, distress scores then remain relatively stable for both groups until Wave 26 (3/17/2021 to 4/27/2021), after which distress declines slightly for respondents who became vaccinated and increases slightly for never vaccinated respondents. Wave 26 corresponds to the median wave of vaccination in our sample. 
medRxiv preprint doi: https://doi.org/10.1101/2021.07.19.21260782; this version posted July 28, 2021. The copyright holder for this preprint (which was not certified by peer review) is the author/funder, who has granted medRxiv a license to display the preprint in perpetuity. It is made available under a CC-BY-NC-ND 4.0 International license .

Figure 2A shows secular trends in risk perceptions for never vaccinated respondents and respondents who became vaccinated during our study period. Here, while respondents who became vaccinated exhibited slightly higher levels of risk perceptions for the majority of the study period, both groups shared similar trends until Wave $25(2 / 17 / 2021$ to 3/29/2021), corresponding to the wave prior to the median wave of vaccination in our sample. Risk perceptions then decline for respondents who became vaccinated, falling below the mean risk perception levels of respondents who did not become vaccinated.

Table 1 shows our difference-in-difference estimates for the association between vaccination and perceived risk of infection in Model 1, perceived risk of hospitalization in Model 2, and perceived risk of death in Model 3. All models adjust for individual and wave fixed effects, and time-varying unemployment insurance, SNAP, and employment status. Here, vaccination is associated with an 8.44 percentage point reduction in perceived risk of infection (95\% CI: $-9.15 \%$ to $-7.73 \%$ ), a 7.44-point reduction in perceived risk of hospitalization (95\% CI: $-8.07 \%$ to $-6.82 \%$ ), and a 5.03-point reduction in perceived risk of death (95\% CI: $-5.57 \%$ to $4.49 \%)$.

Table 2 shows our primary difference-in-difference analyses. In Model 1, receiving vaccination is associated with a -.09 decrease in distress scores ( $<<0.001 ; 95 \%$ CI: -0.15 to 0.04), and this relationship remains unchanged after adjusting for unemployment insurance, SNAP, and employment status in Model 2. This estimate corresponds to a $5.7 \%$ relative reduction in distress compared to mean distress scores in the wave prior to vaccination.

Model 3 adjusts for risk perceptions, which are all independently associated with distress net of each other. A 10-percentage point increase in perceived risk of infection is associated with a 0.04 increase in psychological distress scores ( $\mathrm{p}<0.001 ; 95 \%$ CI: 0.03 to 0.05 ); perceived risk 
medRxiv preprint doi: https://doi.org/10.1101/2021.07.19.21260782; this version posted July 28, 2021. The copyright holder for this preprint (which was not certified by peer review) is the author/funder, who has granted medRxiv a license to display the preprint in perpetuity. It is made available under a CC-BY-NC-ND 4.0 International license .

of hospitalization is associated with a 0.02 increase in psychological distress scores $(\mathrm{p}<0.01$;

95\% CI: 0.01 to 0.03 ); death is associated with a 0.03 increase in psychological distress scores (p $<0.001$; $95 \%$ CI: 0.01 to 0.04). Importantly, adjusting for risk perceptions in Model 3 reduces the coefficient for vaccination by two-thirds, to -0.03 , which is no longer statistically significant $(\mathrm{p}=$ 0.22; $95 \%$ CI: -0.09 to 0.02 ). Taken together, these models suggest that the receiving the COVID-19 vaccination reduces psychological distress, and that this effect is transmitted largely through declines in perceived risk of infection, hospitalization, and death.

The event study analyses in Figures 1 and 2 provide additional support for our findings in Table 2. Figure 1 shows vaccinated and never vaccinated respondents followed similar trends in distress scores prior to vaccination, and that these diverged significantly afterwards, with vaccinated respondents experiencing significant declines in distress. Importantly, these treatment effects persist for 8 weeks post vaccination. It takes a few waves for the effect to be fully realized, which suggests that our regression estimates likely underestimate the true effect. In Figure 2 we observe slight differences in risk perceptions between vaccinated and never vaccinated respondents in the pre-treatment period, although these are stable over time. Following vaccination, these trends diverge, with vaccinated individuals experiencing large reductions risk perceptions relative to those who were never vaccinated in our sample. Finally, Figure 1A (supplement) shows the event study results for the effect of vaccination on distress after adjusting for risk perceptions. Consistent with Model 3 in Table 2, we observe no significant treatment effects of vaccination after accounting for changing risk perceptions associated with vaccination. 
medRxiv preprint doi: https://doi.org/10.1101/2021.07.19.21260782; this version posted July 28, 2021. The copyright holder for this preprint (which was not certified by peer review) is the author/funder, who has granted medRxiv a license to display the preprint in perpetuity.

It is made available under a CC-BY-NC-ND 4.0 International license .

\section{Sensitivity checks}

Figures $4 \mathrm{~A}-8 \mathrm{~A}$ in the supplement test whether the effects of vaccination vary by demographic subgroups. Each figure represents two-way fixed effects models with psychological distress scores regressed on vaccination status stratified by age groups (Figure 4A), race/ethnicity (Figure 5A), education (Figure 6A), gender (Figure 7A), and household income (Figure 8A). Here, we do not observe substantive differences in the effect of vaccination across sociodemographic groups.

Tables 3A-6A show how the patterns described in our main analyses remain robust after using sample weights, restricting our models to respondents aged $65+$, including state-by-wave fixed effects, and when using an indicator for severe psychological (PHQ-4 scores $\geq 9$ ) as the dependent variable. With respect to the latter, we found that vaccination was associated with a 0.6 percentage point reduction in severe distress from a baseline prevalence of $0.04 \%$ in the wave prior to vaccination, corresponding to a $15 \%$ relative decline.

\section{Discussion}

This study has several important findings. First, vaccination was associated with a $5.7 \%$ reduction in PHQ-4 distress scores and a 15\% reduction in severe distress (PHQ-4 scores $\geq 9$ ). Vaccination was also associated with an 8.44 percentage point reduction in perceived risk of infection, a 7.44-point reduction in perceived risk of hospitalization, and a 5.03-point reduction in perceived risk of death. Adjusting for risk perceptions decreased the association between vaccination and distress by two-thirds, to statistical insignificance. Complementary panel event study models suggest that vaccinated and never vaccinated respondents shared similar trends in distress prior to vaccination, and that these trends diverged significantly following vaccination. 
medRxiv preprint doi: https://doi.org/10.1101/2021.07.19.21260782; this version posted July 28, 2021. The copyright holder for this preprint

As with all observational analyses, our study has clear limitations. First, measurements of both the distress and vaccination rely on self-report, which may be biased. Second, the webbased sample may not be truly representative of the US population and individuals from underrepresented racial and ethnic groups. Third, our analysis was designed to capture only the direct effect of an individual becoming vaccinated on their own mental health. However, vaccination is likely to have myriad positive spillover effects on mental health that are not captured in this study. Mental health may improve as friends and family become vaccinated, as the economy rebounds, as community prevalence of virus falls, and as fewer people suffer major illness or death. The respondents in the UCA study likely benefited from vaccine scale-up beyond their own vaccination status. Additionally, their getting vaccinated likely benefited other peoples' mental health. As a result, our findings likely substantially underestimate the beneficial effect of vaccination for mental health at the population level.

Notwithstanding these limitations, our study has several key strengths. First, to our knowledge, this is the first study to assess the psychological impacts of COVID-19 vaccination. Second, our main findings are robust to time-varying controls, individual and wave fixed effects, and several alternative modelling strategies. Importantly, our analyses were robust to state-bywave fixed effects, ruling out confounding due to time-varying factors at the state-level, such as rates of infection or policy implementation. Third, our event study models show that the mental health benefits of vaccination persist for at least 8 weeks, suggesting that these effects are not a signal of fleeting relief.

Our results have important public health and policy implications. Murphy and colleagues(35) suggest that messages tailored to vaccine hesitant or resistant individuals could emphasize the personal benefits of vaccination against COVID-19. We provide an evidence base 
for these personal benefits that underscore mental health improvements following vaccination in a nationally representative sample of U.S. adults. We also demonstrate that vaccination is a key lever in reducing the mental health burdens associated with the COVID-19 pandemic.

Acknowledgements: The project described in this paper relies on data from survey(s) administered by the Understanding America Study, which is maintained by the Center for Economic and Social Research (CESR) at the University of Southern California. The content of this paper is solely the responsibility of the authors and does not necessarily represent the official views of USC or UAS. The collection of the UAS COVID-19 tracking data is supported in part by the Bill \& Melinda Gates Foundation and by grant U01AG054580 from the National Institute on Aging, and many others. The authors would also like to thank Atheendar Venkataramani for his helpful comments on an earlier version of this manuscript.

Competing interests: none to declare. 


\section{Figures and Tables}

Figure 1: Difference-in-differences estimates of the association between receiving the COVID19 vaccine and psychological distress

Figure 2: Difference-in-differences estimates of the association between receiving the COVID19 vaccine and perceived risk factors

Table 1. Two-way fixed effects models with perceived risk factors regressed on vaccination status, April 2020 to June $2021(\mathrm{~N}=5,792)$

Table 2. Two-way fixed effects models with psychological distress (PHQ-4) regressed on vaccination status and perceived risk factors, April 2020 to June $2021(\mathrm{~N}=5,792)$ 
Figure 1. Difference-in-Differences Estimates of the Association Between Receiving the COVID-19 Vaccine and Psychological Distress

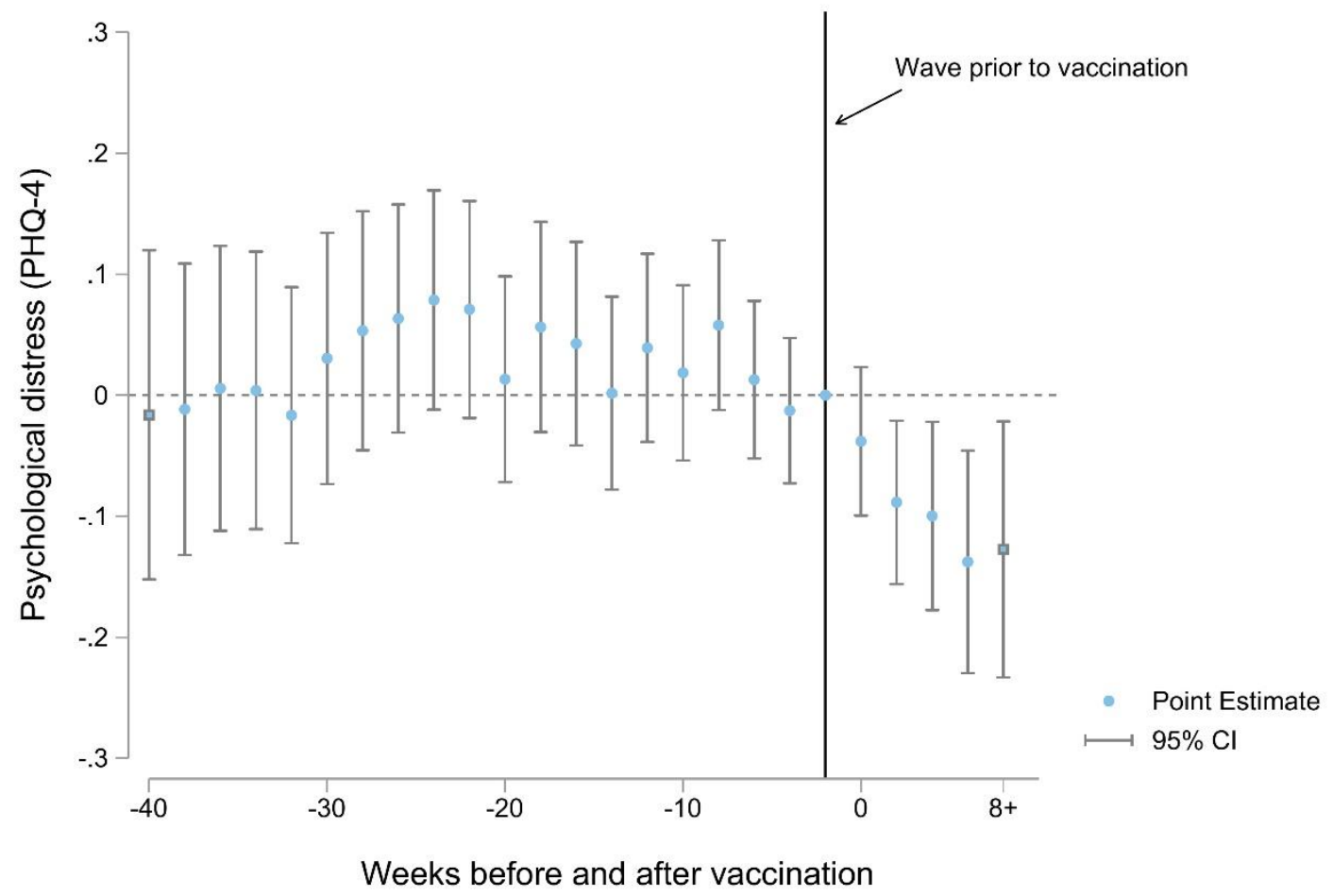

Notes: Each point estimate refers to the change in distress between vaccinated and never vaccinated individuals, compared to their baseline differential in the wave immediately prior to vaccination. Models control for individual and wave fixed effects, receiving Supplemental Nutrition Assistance Program (SNAP) benefits in the month prior to the survey, whether the respondent received unemployment insurance in the past 14 days, and employment status at the time of the survey. 
Figure 2: Difference-in-Differences Estimates of the Association Between Receiving the COVID-19 Vaccine and Perceived Risk Factor
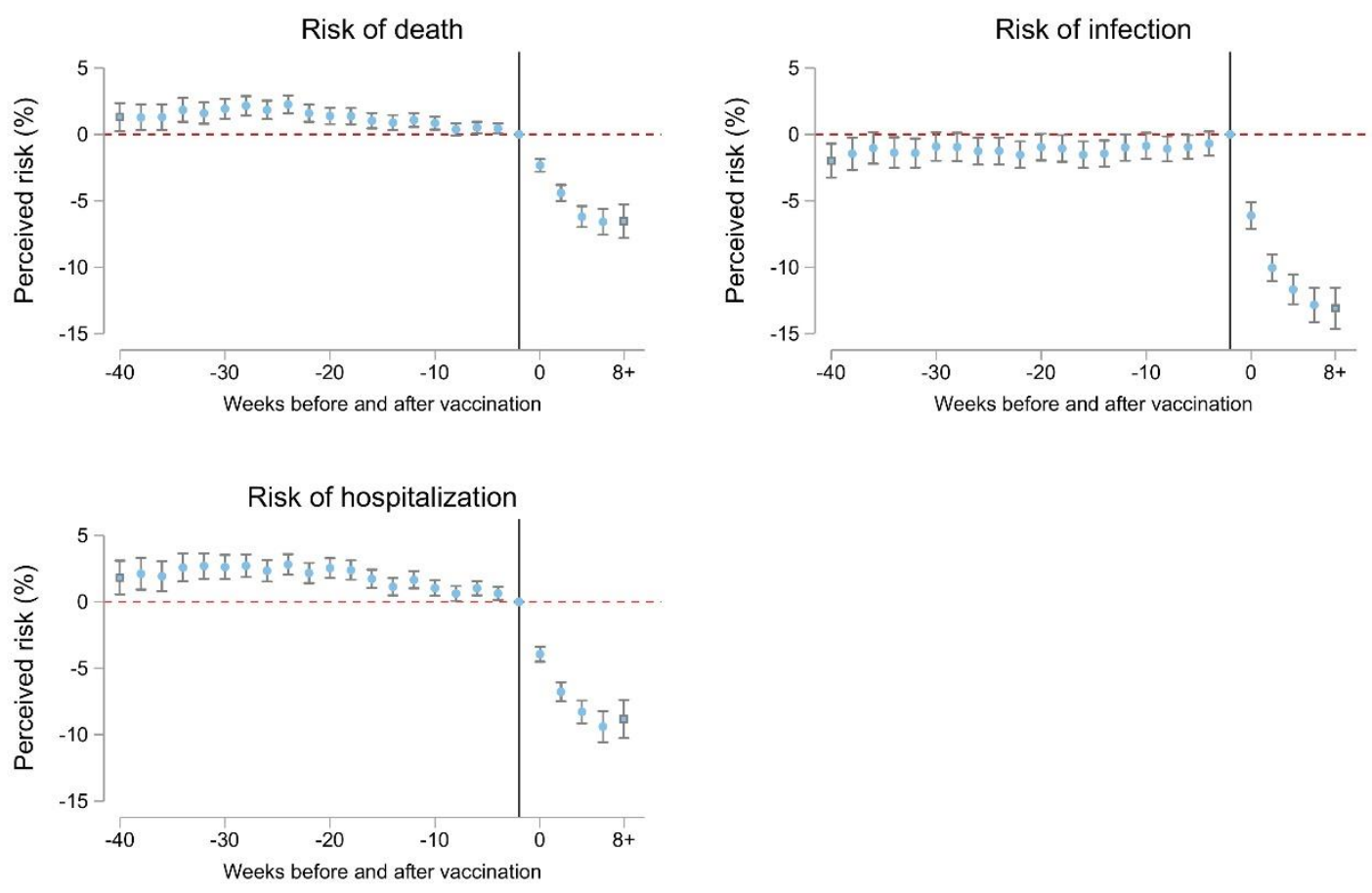

Notes: Each point estimate refers to the change in risk perceptions between vaccinated and never vaccinated individuals, compared to their baseline differential in the wave immediately prior to vaccination (reference line on the $x$-axis). Models control for individual and wave fixed effects, receiving Supplemental Nutrition Assistance Program (SNAP) benefits in the month prior to the survey, whether the respondent received unemployment insurance in the past 14 days, and employment status at the time of the survey. 
Table 1. Two-way fixed effects models with perceived risk factors regressed on vaccination status, April 2020 to June $2021(\mathrm{~N}=5,792)$

\begin{tabular}{|c|c|c|c|c|c|c|}
\hline & \multicolumn{2}{|c|}{ Model 1. Risk of Infection } & \multicolumn{2}{|c|}{ Model 2. Risk of Hospitalization } & \multicolumn{2}{|c|}{ Model 3. Risk of death } \\
\hline & Coef. & $95 \% \mathrm{CI}$ & Coef. & $95 \%$ CI & Coef. & $95 \% \mathrm{CI}$ \\
\hline \multicolumn{7}{|l|}{ Received Vaccination } \\
\hline$(r e f: n o)$ & $-8.44 * * *$ & -9.15 to -7.73 & $-7.44 * * *$ & -8.07 to -6.82 & $-5.03 * * *$ & -5.57 to -4.49 \\
\hline \multicolumn{7}{|l|}{ Received UI (ref: no) } \\
\hline Yes & 0.81 & -0.14 to 1.75 & $0.90^{*}$ & 0.07 to 1.74 & $1.05^{* *}$ & 0.40 to 1.70 \\
\hline Unsure & 1.15 & -0.33 to 2.63 & 0.63 & -1.18 to 2.44 & -0.02 & -1.65 to 1.60 \\
\hline \multicolumn{7}{|l|}{ Received SNAP (ref: no) } \\
\hline Yes & 0.46 & -0.49 to 1.41 & 0.23 & -0.69 to 1.15 & -0.38 & -1.17 to 0.41 \\
\hline Unsure & -1.11 & -2.31 to 0.09 & $-1.32 *$ & -2.64 to -0.00 & -0.57 & -1.79 to 0.66 \\
\hline \multicolumn{7}{|l|}{ Currently working } \\
\hline (ref: $n o)$ & 0.72 & -0.34 to 1.78 & 0.44 & -0.55 to 1.43 & -0.23 & -0.99 to 0.54 \\
\hline Individual fixed effects & Yes & & Yes & & Yes & \\
\hline Wave fixed effects & Yes & & Yes & & Yes & \\
\hline Constant & $21.69 * * *$ & 20.78 to 22.59 & $32.35 * * *$ & 31.25 to 33.46 & $23.49 * * *$ & 22.66 to 24.32 \\
\hline N. of cases & 5,792 & & 5,792 & & 5,792 & \\
\hline
\end{tabular}

$* \mathrm{p}<0.05, * * \mathrm{p}<0.01, * * * \mathrm{p}<0.001$ 
Table 2. Two-way fixed effects models with psychological distress (PHQ-4) regressed on vaccination status and perceived risk factors, April 2020 to June $2021(\mathrm{~N}=5,792)$

\begin{tabular}{|c|c|c|c|c|c|c|}
\hline & \multicolumn{2}{|c|}{ Model 1} & \multicolumn{2}{|c|}{ Model 2} & \multicolumn{2}{|r|}{ Model 3} \\
\hline & Coef. & $95 \% \mathrm{CI}$ & Coef. & $95 \% \mathrm{CI}$ & Coef. & $95 \%$ CI \\
\hline \multicolumn{7}{|l|}{ Received } \\
\hline \multicolumn{7}{|l|}{ Vaccination } \\
\hline (ref: no) & $-0.09 * * *$ & -0.15 to -0.04 & $-0.09 * * *$ & -0.15 to -0.04 & -0.03 & -0.09 to 0.02 \\
\hline \multicolumn{7}{|l|}{ Received UI } \\
\hline \multicolumn{7}{|l|}{ (ref: no) } \\
\hline Yes & & & 0.07 & -0.04 to 0.18 & 0.06 & -0.05 to 0.17 \\
\hline Unsure & & & 0.01 & -0.29 to 0.31 & 0.00 & -0.30 to 0.31 \\
\hline \multicolumn{7}{|l|}{ Received SNAP } \\
\hline \multicolumn{7}{|l|}{ (ref: no) } \\
\hline Yes & & & 0.03 & -0.09 to 0.15 & 0.03 & -0.09 to 0.15 \\
\hline Unsure & & & $-0.22 *$ & -0.40 to -0.04 & $-0.21 *$ & -0.39 to -0.03 \\
\hline \multicolumn{7}{|l|}{ Currently working } \\
\hline \multicolumn{7}{|l|}{ (ref: no) } \\
\hline Yes & & & 0.07 & -0.05 to 0.20 & 0.07 & -0.05 to 0.19 \\
\hline Risk of infection & & & & & $0.04 * * *$ & 0.03 to 0.05 \\
\hline \multicolumn{7}{|l|}{ Risk of } \\
\hline \multicolumn{7}{|l|}{ Hospitalization } \\
\hline Risk of death & & & & & $0.03 * * *$ & 0.01 to 0.04 \\
\hline $\begin{array}{l}\text { Individual fixed } \\
\text { effects }\end{array}$ & Yes & & Yes & & Yes & \\
\hline Wave fixed effects & Yes & & Yes & & Yes & \\
\hline Constant & $2.25 * * *$ & 2.17 to 2.33 & $2.21 * * *$ & 2.10 to 2.32 & $2.00 * * *$ & 1.89 to 2.12 \\
\hline N. of cases & 5,792 & & 5,792 & & 5,792 & \\
\hline
\end{tabular}

$* \mathrm{p}<0.05, * * \mathrm{p}<0.01, * * * \mathrm{p}<0.001$

Notes: Standard errors are clustered at the individual level. Coefficients for perceived risk factors are expressed as a 10percentage point increase. 
medRxiv preprint doi: https://doi.org/10.1101/2021.07.19.21260782; this version posted July 28, 2021. The copyright holder for this preprint (which was not certified by peer review) is the author/funder, who has granted medRxiv a license to display the preprint in perpetuity.

\section{Supplementary Figures and Tables}

Figure 1A: Unadjusted temporal trend in psychological distress among vaccinated respondents before and after vaccination, March 2020 to June 2021

Figure 2A: Unadjusted temporal trends in risk perceptions among vaccinated respondents before and after vaccination, March 2020 to June 2021

Figure 3A: Difference-in-Differences Estimates of the Association Between Receiving the COVID-19 Vaccine and Psychological Distress (including risk factors as mediators)

Figure 4A. Two-way fixed effects models with psychological distress (PHQ-4) regressed on the vaccination status, stratified by age categories, April 2020 to June 2021

Figure 5A. Two-way fixed effects models with psychological distress (PHQ-4) regressed on vaccination status, stratified by self-reported race/ethnicity, April 2020 to June 2021

Figure 6A. Two-way fixed effects models with psychological distress (PHQ-4) regressed on vaccination status, stratified by education, April 2020 to June 2021

Figure 7A. Two-way fixed effects models with psychological distress (PHQ-4) regressed on vaccination status, stratified by gender, April 2020 to June 2021

Figure 8A. Two-way fixed effects models with psychological distress (PHQ-4) regressed on vaccination status, stratified by household income, April 2020 to June 2021

Table A1. Timing of data collection for each wave of the Understanding Coronavirus in America

Table 2A: Characteristics of sample by vaccination status

Table 3A. Two-way fixed effects models with psychological distress (PHQ-4) regressed on vaccination status and perceived risk factors using sample weights, April 2020 to June 2021 (N= 5,792)

Table 4A. Two-way fixed effects models with psychological distress (PHQ-4) regressed on vaccination status and perceived risk factors among respondents aged 65 and above, April 2020 to June $2021(\mathrm{~N}=1,473)$

Table 5A. Two-way fixed effects models with severe psychological distress (PHQ-4 scores $\geq 9$ ) regressed on vaccination status and perceived risk factors, April 2020 to June $2021(\mathrm{~N}=5,792)$

Table 6A. Two-way fixed effects models with severe psychological distress (PHQ-4 scores 9 and above) regressed on vaccination status and perceived risk factors adjusting for state-by-wave fixed effects, April 2020 to June 2021 (N= 5,788) 
medRxiv preprint doi: https://doi.org/10.1101/2021.07.19.21260782; this version posted July 28, 2021. The copyright holder for this preprint (which was not certified by peer review) is the author/funder, who has granted medRxiv a license to display the preprint in perpetuity. It is made available under a CC-BY-NC-ND 4.0 International license.

Figure 1A: Unadjusted temporal trends in psychological distress over 28 waves in the Understanding Coronavirus in America study, March 2020 to June 2021

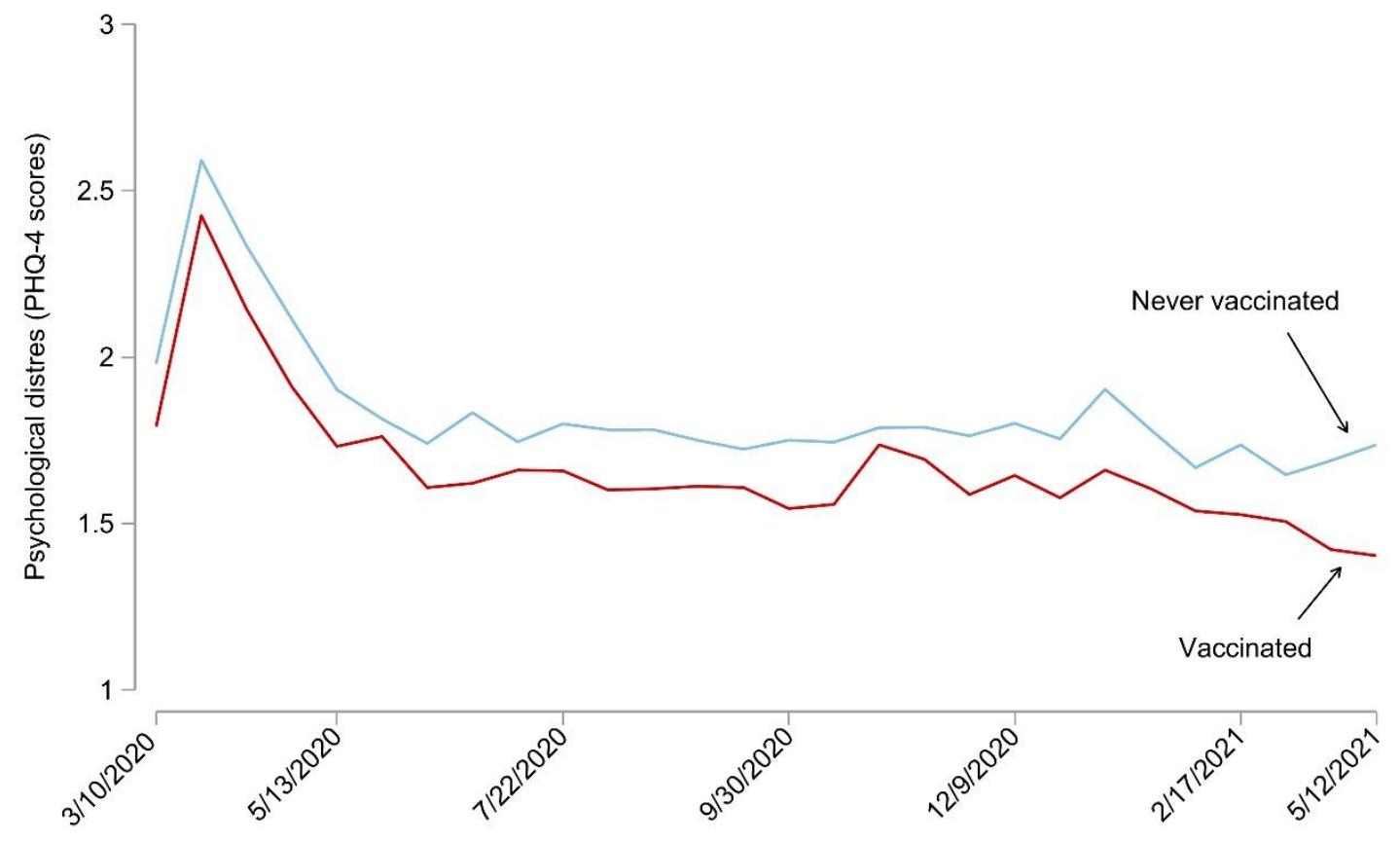

Study wave start date 
medRxiv preprint doi: https://doi.org/10.1101/2021.07.19.21260782; this version posted July 28, 2021. The copyright holder for this preprint (which was not certified by peer review) is the author/funder, who has granted medRxiv a license to display the preprint in perpetuity.

It is made available under a CC-BY-NC-ND 4.0 International license.

Figure 2A: Unadjusted temporal trends in risk perceptions over 28 waves in the Understanding Coronavirus in America study, March 2020 to June 2021
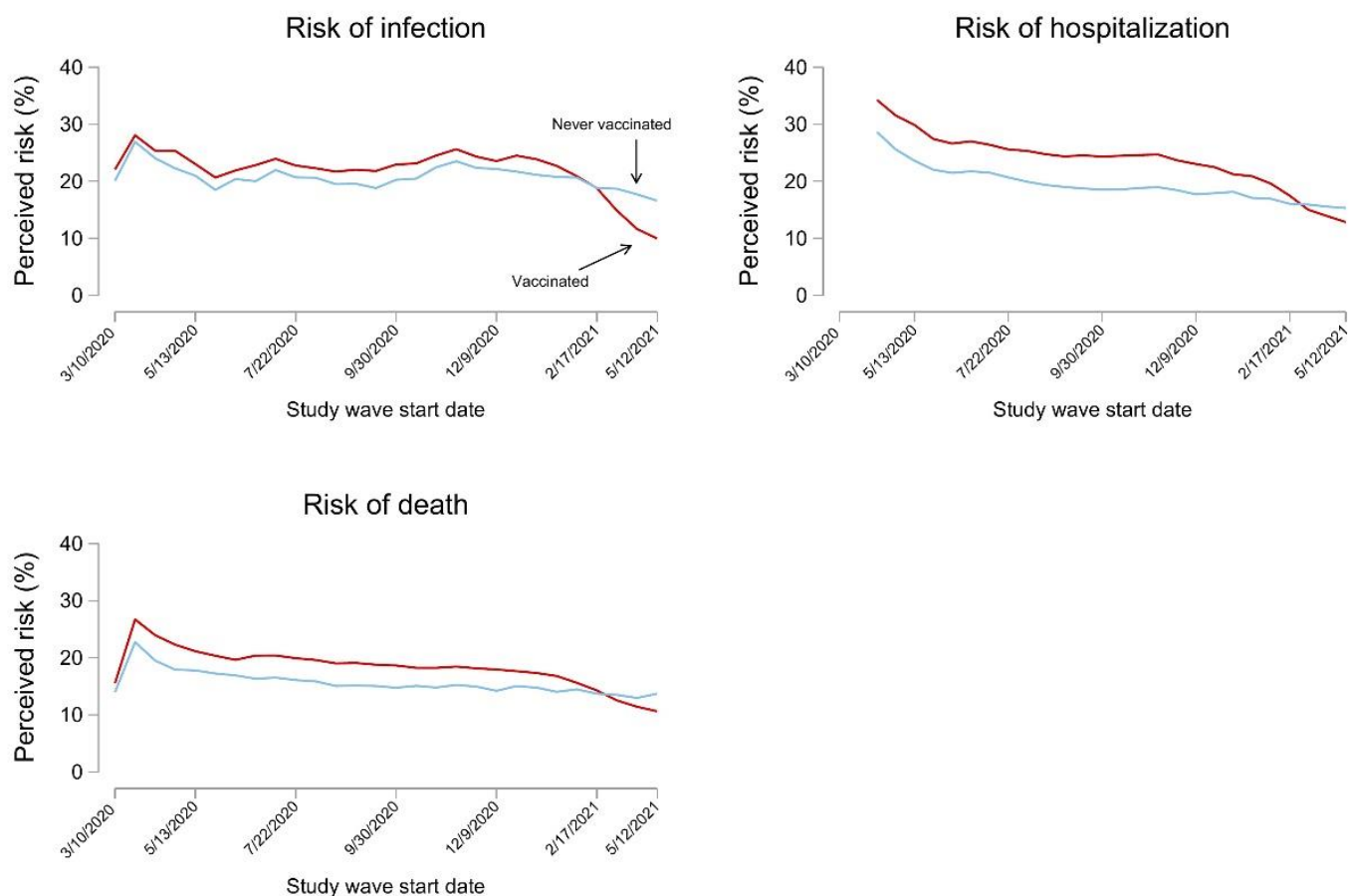

Notes: Red lines are secular trends in risk perceptions over time for respondents who became vaccinated. Blue lines are secular trends over time for respondents who did not become vaccinated. 
Figure 3A: Difference-in-Differences Estimates of the Association Between Receiving the COVID-19 Vaccine and Psychological Distress (including risk factors as mediators)

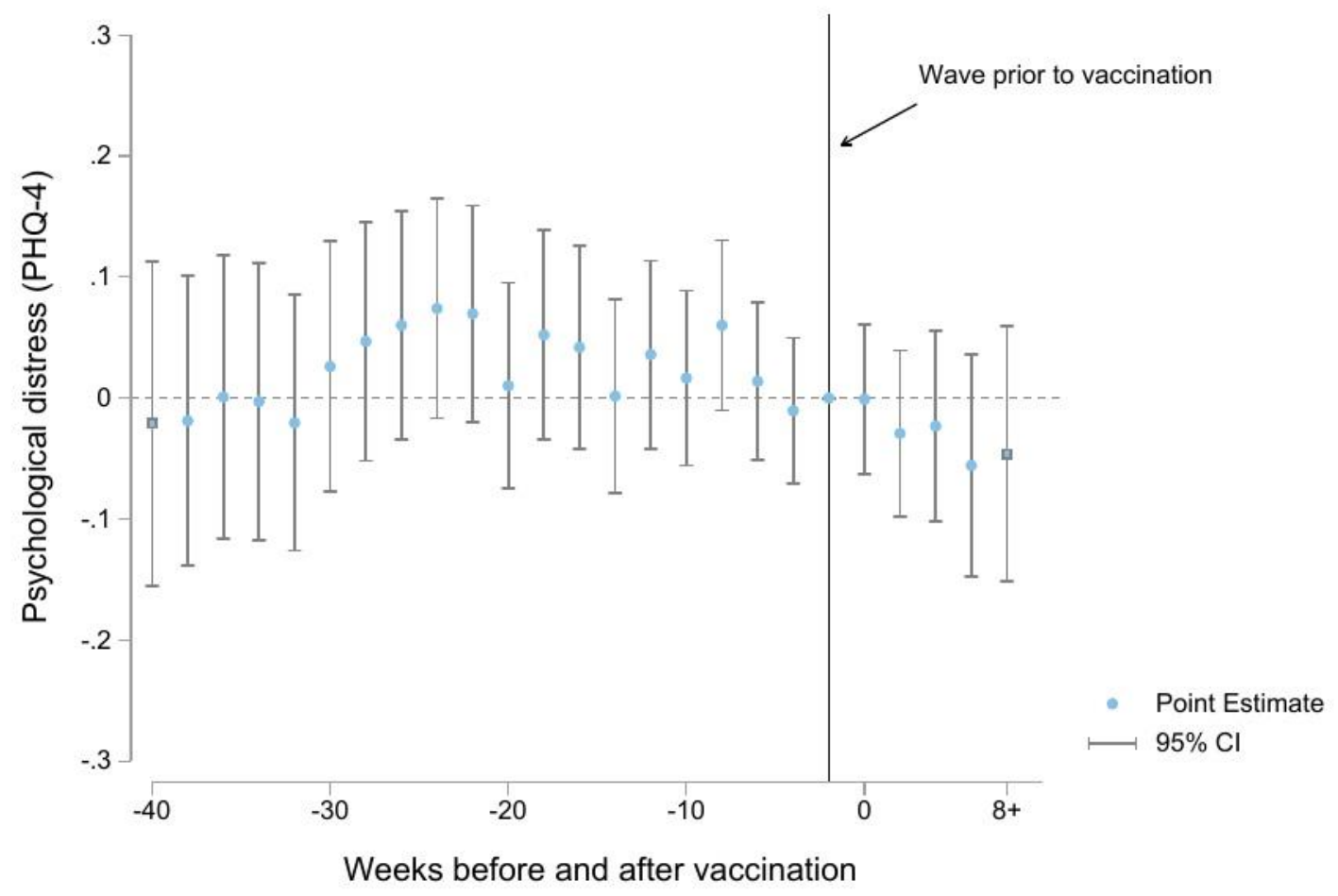

Notes: Each point estimate refers to the change in distress between vaccinated and never vaccinated individuals, compared to their baseline differential in the wave immediately prior to vaccination. Models control for individual and wave fixed effects, receiving Supplemental Nutrition Assistance Program (SNAP) benefits in the month prior to the survey, whether the respondent received unemployment insurance in the past 14 days, and employment status at the time of the survey. 
Figure 4A. Two-way fixed effects models with psychological distress (PHQ-4) regressed on vaccination status, stratified by age, April 2020 to June 2021

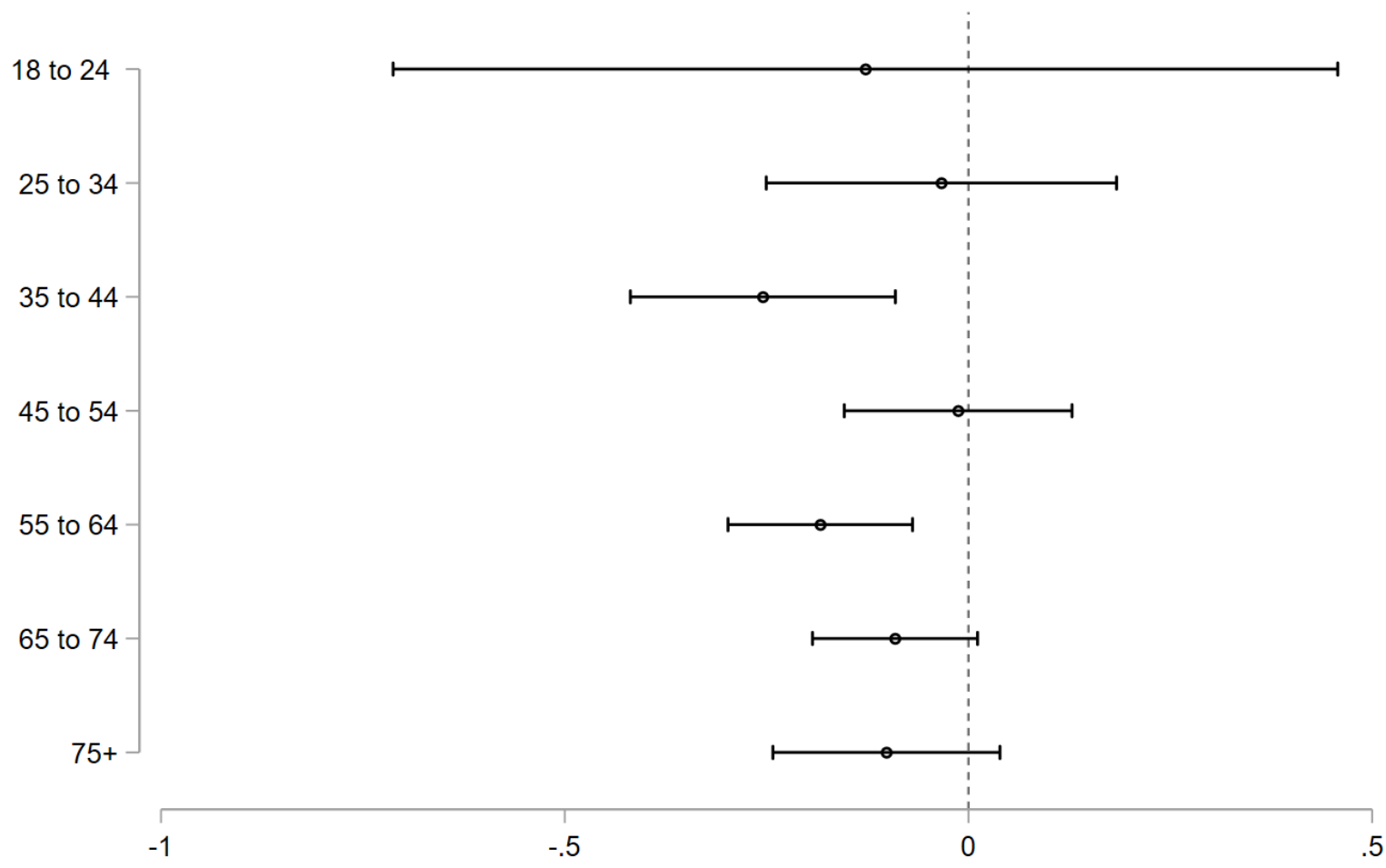

Coefficients for the association between vaccination and distress

Notes: Point estimates and 95\% confidence intervals are from separate two-way fixed effects models stratified by subgroup. Models control for individual and wave fixed effects, receiving Supplemental Nutrition Assistance Program (SNAP) benefits in the month prior to the survey, whether the respondent received unemployment insurance in the past 14 days, and employment status at the time of the survey. Standard errors are clustered at the individual level. 
Figure 5A. Two-way fixed effects models with psychological distress (PHQ-4) regressed on vaccination status, stratified by self-reported race/ethnicity, April 2020 to June 2021

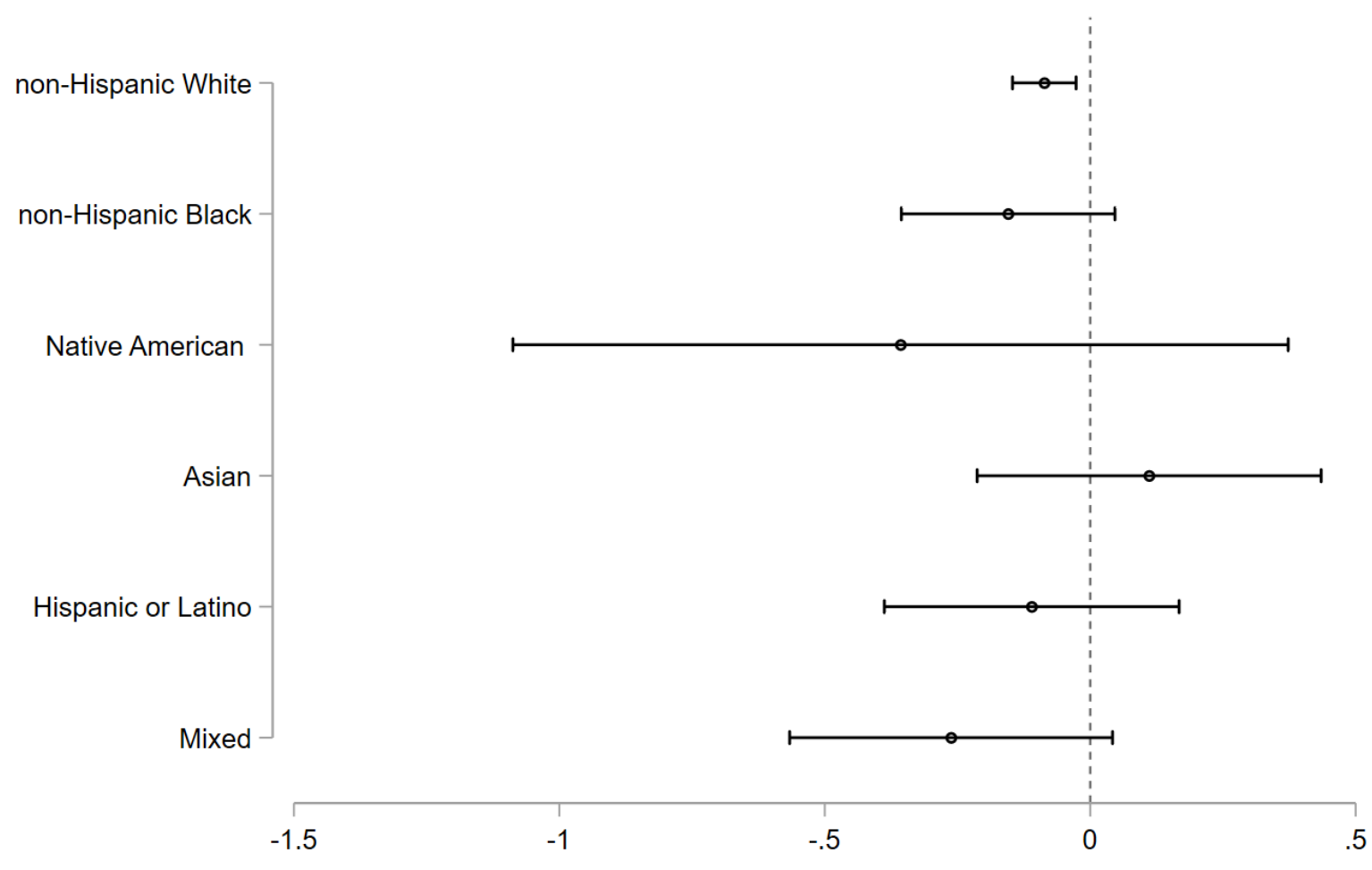

Coefficients for the association between vaccination and distress

Notes: Point estimates and 95\% confidence intervals are from separate two-way fixed effects models stratified by subgroup. Native Hawaiian or Other Pacific Islander respondents were combined with Asian respondents due to extremely small cell sizes for the former groups. Models control for individual and wave fixed effects, receiving Supplemental Nutrition Assistance Program (SNAP) benefits in the month prior to the survey, whether the respondent received unemployment insurance in the past 14 days, and employment status at the time of the survey. Standard errors are clustered at the individual level. 
Figure 6A. Two-way fixed effects models with psychological distress (PHQ-4) regressed on vaccination status, stratified by education, April 2020 to June 2021

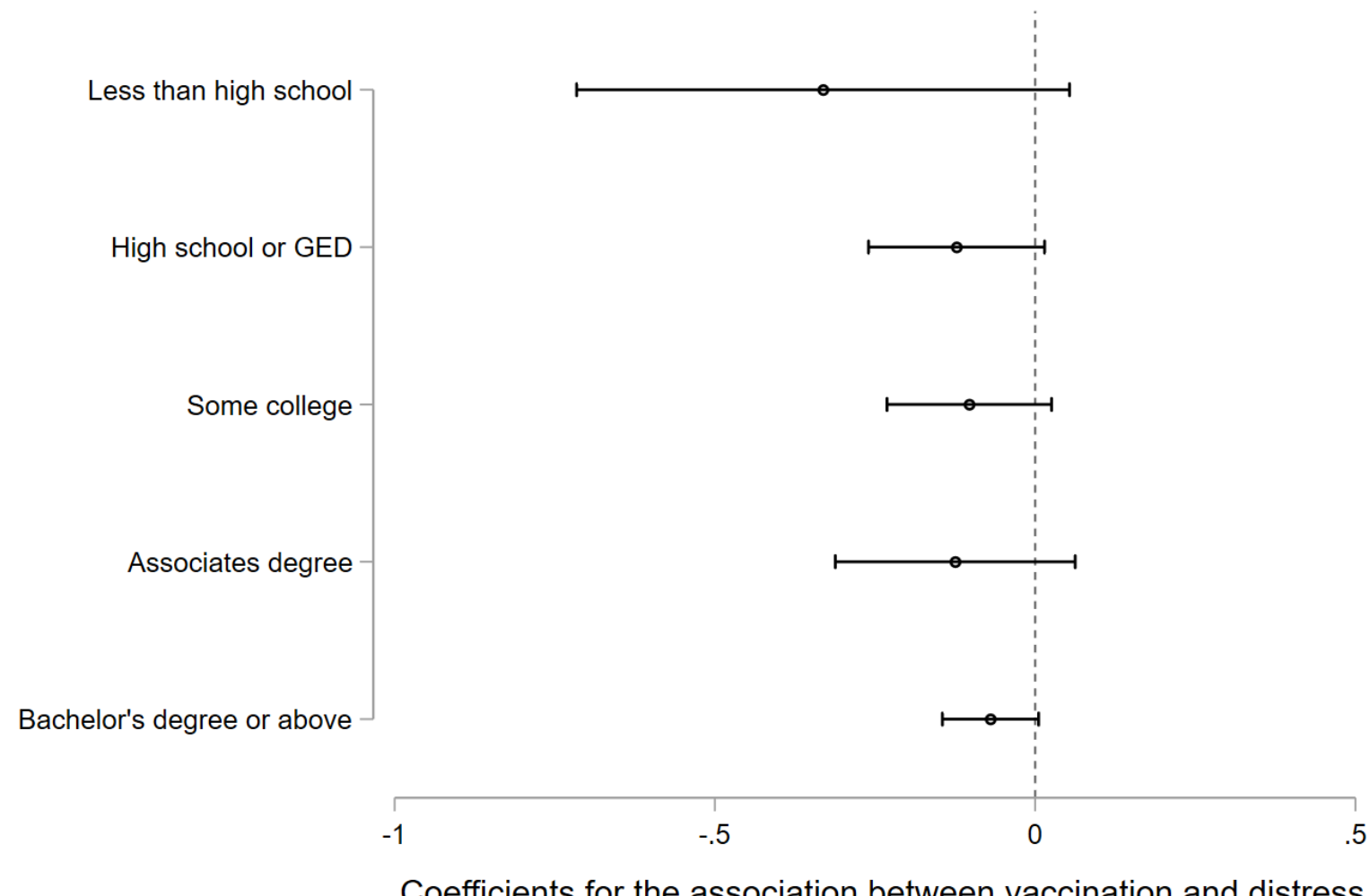

Notes: Point estimates and 95\% confidence intervals are from separate two-way fixed effects models stratified by subgroup. Models control for individual and wave fixed effects, receiving Supplemental Nutrition Assistance Program (SNAP) benefits in the month prior to the survey, whether the respondent received unemployment insurance in the past 14 days, and employment status at the time of the survey. Standard errors are clustered at the individual level. 
Figure 7A. Two-way fixed effects models with psychological distress (PHQ-4) regressed on vaccination status, stratified by gender, April 2020 to June 2021

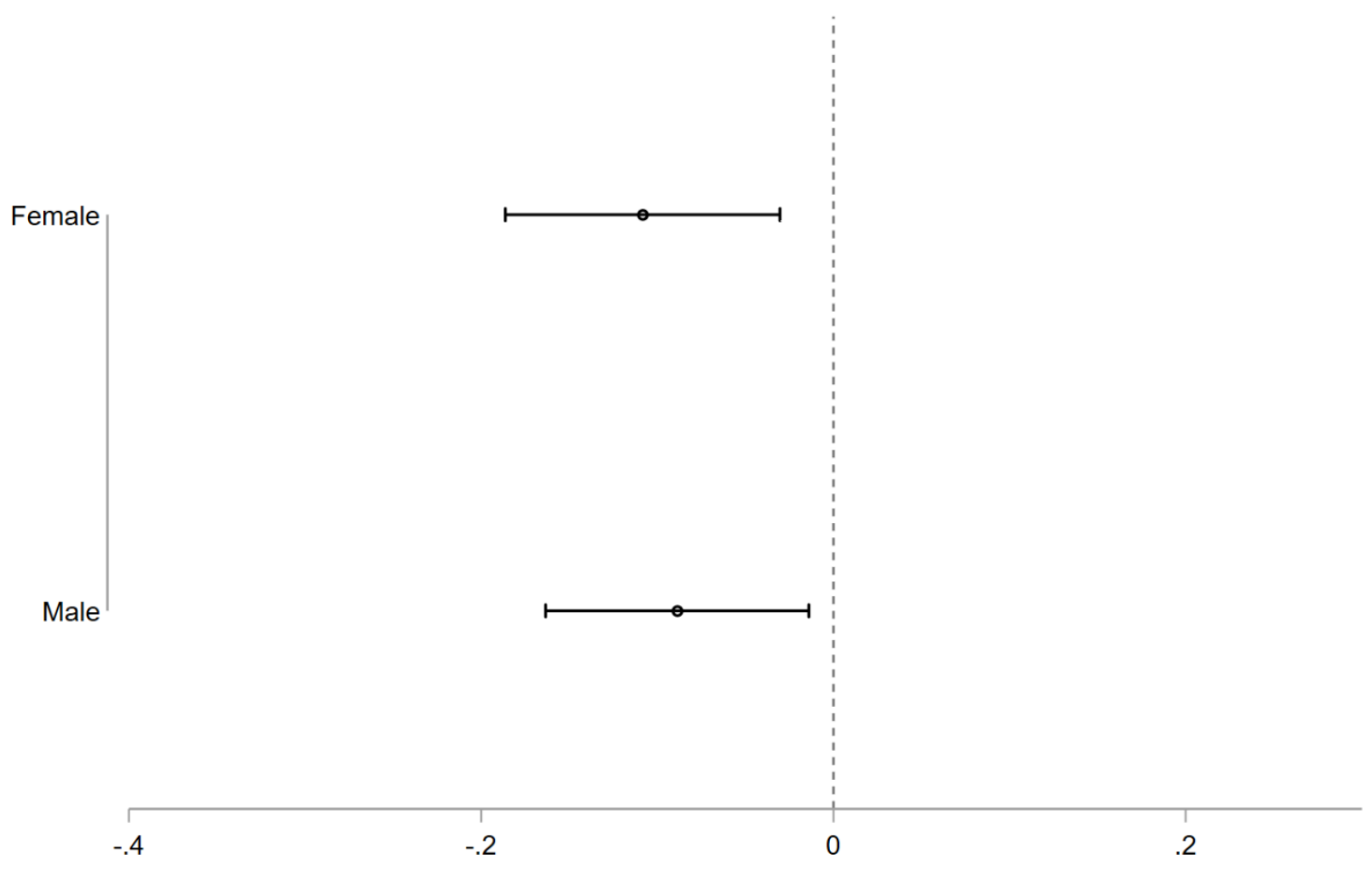

Coefficients for the association between vaccination and distress

Notes: Point estimates and 95\% confidence intervals are from separate two-way fixed effects models stratified by subgroup. Models control for individual and wave fixed effects, receiving Supplemental Nutrition Assistance Program (SNAP) benefits in the month prior to the survey, whether the respondent received unemployment insurance in the past 14 days, and employment status at the time of the survey. Standard errors are clustered at the individual level. 
Figure 8A. Two-way fixed effects models with psychological distress (PHQ-4) regressed on vaccination status, stratified by household income, April 2020 to June 2021

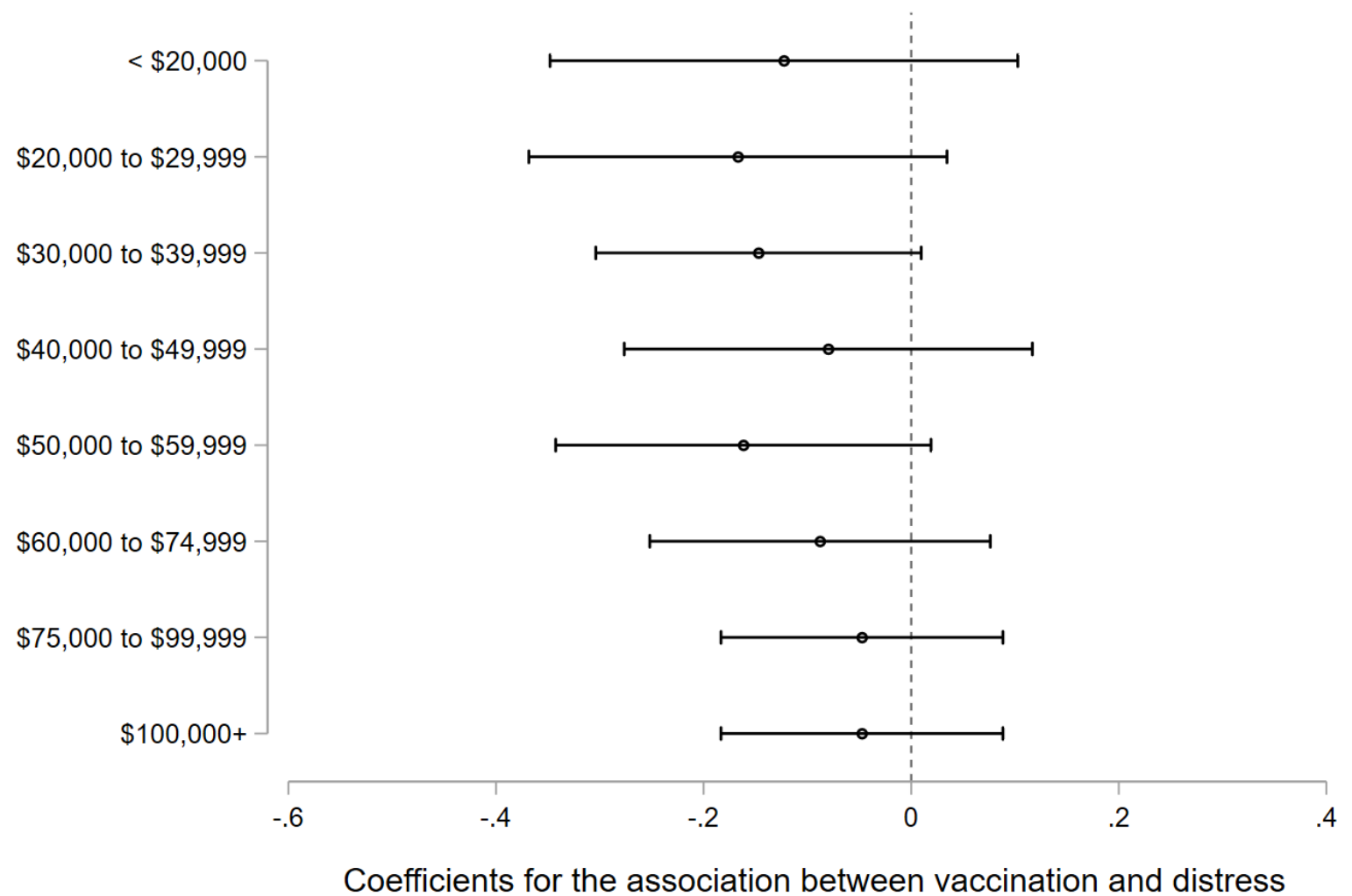

Notes: Point estimates and 95\% confidence intervals are from separate two-way fixed effects models stratified by subgroup. Models control for individual and wave fixed effects, receiving Supplemental Nutrition Assistance Program (SNAP) benefits in the month prior to the survey, whether the respondent received unemployment insurance in the past 14 days, and employment status at the time of the survey. Standard errors are clustered at the individual level. 
Table A1. Timing of data collection for each wave of the Understanding Coronavirus in America

\begin{tabular}{rrr}
\hline Wave & Date begin & Date close \\
\hline 1 & $3 / 10 / 2020$ & $3 / 31 / 2020$ \\
2 & $4 / 1 / 2020$ & $4 / 27 / 2020$ \\
3 & $4 / 15 / 2020$ & $5 / 11 / 2020$ \\
4 & $4 / 29 / 2020$ & $5 / 25 / 2020$ \\
5 & $5 / 13 / 2020$ & $6 / 8 / 2020$ \\
6 & $5 / 27 / 2020$ & $6 / 22 / 2020$ \\
7 & $6 / 10 / 2020$ & $7 / 6 / 2020$ \\
8 & $6 / 24 / 2020$ & $7 / 20 / 2020$ \\
9 & $7 / 8 / 2020$ & $8 / 3 / 2020$ \\
10 & $7 / 22 / 2020$ & $8 / 17 / 2020$ \\
11 & $8 / 5 / 2020$ & $8 / 31 / 2020$ \\
12 & $8 / 19 / 2020$ & $9 / 14 / 2020$ \\
13 & $9 / 2 / 2020$ & $9 / 28 / 2020$ \\
14 & $9 / 16 / 2020$ & $10 / 12 / 2020$ \\
15 & $9 / 30 / 2020$ & $10 / 26 / 2020$ \\
16 & $10 / 14 / 2020$ & $11 / 9 / 2020$ \\
17 & $10 / 28 / 2020$ & $11 / 23 / 2020$ \\
18 & $11 / 11 / 2020$ & $12 / 7 / 2020$ \\
19 & $11 / 25 / 2020$ & $12 / 21 / 2020$ \\
20 & $12 / 9 / 2020$ & $1 / 4 / 2021$ \\
21 & $12 / 23 / 2020$ & $1 / 18 / 2021$ \\
22 & $1 / 6 / 2021$ & $2 / 1 / 2021$ \\
23 & $1 / 20 / 2021$ & $2 / 15 / 2021$ \\
24 & $2 / 3 / 2021$ & $3 / 1 / 2021$ \\
25 & $2 / 17 / 2021$ & $3 / 29 / 2021$ \\
26 & $3 / 17 / 2021$ & $4 / 27 / 2021$ \\
27 & $4 / 14 / 2021$ & $5 / 25 / 2021$ \\
28 & $5 / 12 / 2021$ & $6 / 22 / 2021$ \\
\hline
\end{tabular}

Notes: Waves 1 and 9 excluded from our TWFE and event study models because core questions were not asked in these periods. New UCA surveys are fielded every two weeks. Each day one fourteenth of participants are invited to take the survey, and participants have two weeks to take the survey meaning that the total field period for each wave of the survey is 4 weeks and there is overlap between waves. Participants are incentivized to respond to the survey on the day they are invited to participate. 
Table 2A: Characteristics of sample by vaccination status

\begin{tabular}{|c|c|c|c|}
\hline & $\begin{array}{l}\text { Vaccinated } \\
(57 \%)\end{array}$ & $\begin{array}{c}\text { Never Vaccinated } \\
(43 \%)\end{array}$ & P-value \\
\hline Household income $(\$)$ & & & $<0.001$ \\
\hline$<20,000$ & $36 \%$ & $64 \%$ & \\
\hline 20,000 to 29,999 & $48 \%$ & $52 \%$ & \\
\hline 30,000 to 39,999 & $50 \%$ & $50 \%$ & \\
\hline 40,000 to 49,999 & $59 \%$ & $41 \%$ & \\
\hline 50,000 to 59,999 & $53 \%$ & $47 \%$ & \\
\hline 60,000 to 74,999 & $59 \%$ & $41 \%$ & \\
\hline 75,000 to 99,999 & $63 \%$ & $37 \%$ & \\
\hline $100,000+$ & $68 \%$ & $32 \%$ & \\
\hline$\underline{\text { Education }}$ & & & $<0.001$ \\
\hline Less than high school & $35 \%$ & $65 \%$ & \\
\hline High school or GED & $41 \%$ & $59 \%$ & \\
\hline Some college & $49 \%$ & $51 \%$ & \\
\hline Assoc. degree & $55 \%$ & $46 \%$ & \\
\hline Bachelor's or higher & $68 \%$ & $32 \%$ & \\
\hline$\underline{\text { Race }}$ & & & $<0.001$ \\
\hline White & $57 \%$ & $43 \%$ & \\
\hline Black & $48 \%$ & $52 \%$ & \\
\hline American Indian or Alaska Native & $38 \%$ & $62 \%$ & \\
\hline Asian & $69 \%$ & $31 \%$ & \\
\hline Hawaiian/Pacific Islander & $59 \%$ & $41 \%$ & \\
\hline Mixed & $49 \%$ & $51 \%$ & \\
\hline$\underline{\text { Hispanic }}$ & $47 \%$ & $53 \%$ & $<0.001$ \\
\hline$\underline{\text { Gender }}$ & & & $<0.001$ \\
\hline Male & $59 \%$ & $41 \%$ & \\
\hline Female & $54 \%$ & $46 \%$ & \\
\hline Marital status & & & $<0.001$ \\
\hline Married (spouse lives with respondent) & $61 \%$ & $39 \%$ & \\
\hline Married (spouse lives elsewhere) & $41 \%$ & $59 \%$ & \\
\hline Separated & $36 \%$ & $64 \%$ & \\
\hline Divorced & $55 \%$ & $45 \%$ & \\
\hline Widowed & $60 \%$ & $40 \%$ & \\
\hline Never married & $45 \%$ & $55 \%$ & \\
\hline$\underline{\text { Age categories }}$ & & & $<0.001$ \\
\hline 18 to 24 & $34 \%$ & $66 \%$ & \\
\hline 25 to 34 & $35 \%$ & $65 \%$ & \\
\hline 35 to 44 & $45 \%$ & $55 \%$ & \\
\hline 45 to 54 & $55 \%$ & $45 \%$ & \\
\hline 55 to 64 & $62 \%$ & $39 \%$ & \\
\hline 65 to 74 & $78 \%$ & $22 \%$ & \\
\hline $75+$ & $80 \%$ & $20 \%$ & \\
\hline
\end{tabular}

Note: Characteristics are unweighted and based on the first observation for each participant in the sample. Pvalues are from chi-square tests of the bivariate association between the demographic group and a dichotomous 
medRxiv preprint doi: https://doi.org/10.1101/2021.07.19.21260782; this version posted July 28, 2021. The copyright holder for this preprint (which was not certified by peer review) is the author/funder, who has granted medRxiv a license to display the preprint in perpetuity.

It is made available under a CC-BY-NC-ND 4.0 International license .

variable that equals 1 if the respondent indicates being vaccinated in any wave of the survey and 0 if never vaccinated.

Table 3A. Two-way fixed effects models with psychological distress (PHQ-4) regressed on vaccination status and perceived risk factors using sample weights, April 2020 to June 2021 ( $N=$ 5,792)

\begin{tabular}{|c|c|c|c|c|c|c|}
\hline & \multicolumn{2}{|c|}{ Model 1} & \multicolumn{2}{|c|}{ Model 2} & \multicolumn{2}{|c|}{ Model 3} \\
\hline & Coef. & $95 \% \mathrm{CI}$ & Coef. & $95 \% \mathrm{CI}$ & Coef. & $95 \% \mathrm{CI}$ \\
\hline $\begin{array}{l}\text { Received Vaccination } \\
\text { (ref: } \text { no) }\end{array}$ & $-0.08^{*}$ & -0.15 to -0.01 & $-0.08^{*}$ & -0.15 to -0.01 & -0.03 & -0.10 to 0.04 \\
\hline \multicolumn{7}{|l|}{ Received UI (ref: no) } \\
\hline Yes & & & 0.06 & -0.10 to 0.23 & 0.06 & -0.11 to 0.22 \\
\hline Unsure & & & 0.12 & -0.23 to 0.47 & 0.12 & -0.24 to 0.47 \\
\hline \multicolumn{7}{|l|}{ Received SNAP (ref: no) } \\
\hline Yes & & & -0.02 & -0.15 to 0.11 & -0.02 & -0.15 to 0.11 \\
\hline Unsure & & & $-0.36^{* *}$ & -0.58 to -0.13 & $-0.35 * *$ & $\begin{array}{l}-0.58 \text { to }- \\
0.12\end{array}$ \\
\hline \multicolumn{7}{|l|}{$\begin{array}{l}\text { Currently working (ref: } \\
\text { no) }\end{array}$} \\
\hline Yes & & & $0.22 * *$ & 0.06 to 0.38 & $0.22 * *$ & 0.06 to 0.38 \\
\hline Risk of death & & & & & $0.03 * *$ & 0.01 to 0.05 \\
\hline Risk of infection & & & & & $0.04 * * *$ & 0.02 to 0.05 \\
\hline Risk of Hospitalization & & & & & 0.01 & -0.00 to 0.03 \\
\hline Individual fixed effects & Yes & & Yes & & Yes & \\
\hline Wave fixed effects & Yes & & Yes & & Yes & \\
\hline Constant & $2.25 * * *$ & 2.13 to 2.37 & $2.13 * * *$ & 1.99 to 2.28 & $1.94 * * *$ & 1.78 to 2.09 \\
\hline N. of cases & 5,792 & & 5,792 & & 5,792 & \\
\hline
\end{tabular}

$* \mathrm{p}<0.05, * * \mathrm{p}<0.01, * * * \mathrm{p}<0.001$


medRxiv preprint doi: https://doi.org/10.1101/2021.07.19.21260782; this version posted July 28, 2021. The copyright holder for this preprint (which was not certified by peer review) is the author/funder, who has granted medRxiv a license to display the preprint in perpetuity.

It is made available under a CC-BY-NC-ND 4.0 International license .

Table 4A. Two-way fixed effects models with psychological distress (PHQ-4) regressed on vaccination status and perceived risk factors among respondents aged 65 and above, April 2020 to June $2021(\mathrm{~N}=1,473)$

\begin{tabular}{|c|c|c|c|c|c|c|}
\hline & \multicolumn{2}{|c|}{ Model 1} & \multicolumn{2}{|c|}{ Model 2} & \multicolumn{2}{|c|}{ Model 3} \\
\hline & Coef. & $95 \% \mathrm{CI}$ & Coef. & $95 \% \mathrm{CI}$ & Coef. & $95 \% \mathrm{CI}$ \\
\hline $\begin{array}{l}\text { Received Vaccination } \\
\text { (ref: no) }\end{array}$ & $-0.10^{*}$ & -0.18 to -0.01 & $-0.09 *$ & -0.18 to -0.01 & -0.05 & -0.14 to 0.03 \\
\hline Received UI (ref: no) & & & & & & \\
\hline Yes & & & 0.14 & -0.04 to 0.33 & 0.14 & -0.04 to 0.33 \\
\hline Unsure & & & 0.43 & -0.30 to 1.16 & 0.42 & -0.30 to 1.14 \\
\hline $\begin{array}{l}\text { Received SNAP (ref: } \\
\text { no) }\end{array}$ & & & & & & \\
\hline Yes & & & -0.03 & -0.29 to 0.23 & -0.03 & -0.28 to 0.23 \\
\hline Unsure & & & 0.00 & -0.34 to 0.33 & 0.01 & -0.33 to 0.35 \\
\hline $\begin{array}{l}\text { Currently working (ref: } \\
\text { no) } \\
\text { Yes }\end{array}$ & & & & & & \\
\hline Risk of death & & & & & 0.01 & -0.01 to 0.03 \\
\hline Risk of infection & & & & & $0.03 * * *$ & 0.01 to 0.04 \\
\hline Risk of Hospitalization & & & & & $0.01 *$ & 0.00 to 0.03 \\
\hline Individual fixed effects & Yes & & Yes & & Yes & \\
\hline Wave fixed effects & Yes & & Yes & & Yes & \\
\hline Constant & $1.47 * * *$ & 1.37 to 1.56 & $1.45^{* * *}$ & 1.35 to 1.55 & $1.31 * * *$ & 1.19 to 1.43 \\
\hline N. of cases & 1,473 & & 1,473 & & 1,473 & \\
\hline
\end{tabular}

$* \mathrm{p}<0.05, * * \mathrm{p}<0.01, * * * \mathrm{p}<0.001$ 
medRxiv preprint doi: https://doi.org/10.1101/2021.07.19.21260782; this version posted July 28, 2021. The copyright holder for this preprint (which was not certified by peer review) is the author/funder, who has granted medRxiv a license to display the preprint in perpetuity.

It is made available under a CC-BY-NC-ND 4.0 International license .

Table 5A. Two-way fixed effects models with severe psychological distress (PHQ-4 scores $\geq 9$ ) regressed on vaccination status and perceived risk factors, April 2020 to June $2021(\mathrm{~N}=5,792)$

\begin{tabular}{|c|c|c|c|c|c|c|}
\hline & \multicolumn{2}{|r|}{ Model 1} & \multicolumn{2}{|c|}{ Model 2} & \multicolumn{2}{|r|}{ Model 3} \\
\hline & Coef. & $95 \% \mathrm{CI}$ & Coef. & $95 \% \mathrm{CI}$ & Coef. & $95 \% \mathrm{CI}$ \\
\hline $\begin{array}{l}\text { Received Vaccination } \\
\text { (ref: no) }\end{array}$ & $-0.006^{*}$ & $-0.011,-0.001$ & $-0.006^{*}$ & $-0.011,-0.001$ & -0.003 & $-0.008,0.002$ \\
\hline \multicolumn{7}{|l|}{ Received UI (ref: no) } \\
\hline Yes & & & -0.004 & $-0.014,0.005$ & -0.004 & -0.014 to 0.005 \\
\hline $\begin{array}{l}\text { Unsure } \\
\text { Received SNAP (ref: } \\
\text { no) }\end{array}$ & & & -0.008 & $-0.033,0.016$ & -0.009 & -0.033 to 0.016 \\
\hline Yes & & & -0.005 & -0.017 to 0.007 & -0.005 & -0.017 to 0.007 \\
\hline Unsure & & & -0.014 & -0.031 to 0.002 & -0.014 & -0.030 to 0.002 \\
\hline \multicolumn{7}{|l|}{$\begin{array}{l}\text { Currently working (ref: } \\
\text { no) }\end{array}$} \\
\hline Yes & & & 0.008 & -0.004 to 0.019 & 0.007 & -0.004 to 0.019 \\
\hline Risk of death & & & & & $0.001 *$ & 0.000 to 0.003 \\
\hline Risk of infection & & & & & $0.002 * * *$ & 0.001 to 0.003 \\
\hline Risk of Hospitalization & & & & & 0.000 & -0.001 to 0.001 \\
\hline \multicolumn{7}{|l|}{ Individual fixed effects } \\
\hline Wave fixed effects & & & & & & \\
\hline Constant & $0.064 * * *$ & 0.055 to 0.072 & $0.061^{* * *}$ & 0.050 to 0.071 & $0.051^{* * *}$ & 0.040 to 0.063 \\
\hline N. of cases & 5,792 & & 5,792 & & 5,792 & \\
\hline
\end{tabular}

$* \mathrm{p}<0.05, * * \mathrm{p}<0.01, * * * \mathrm{p}<0.001$

Notes: Coefficients are from linear probability models. Severe distress is coded 1 if PHQ-4 scores are equal to or greater than 9 and coded 0 for scores below 9 . 
medRxiv preprint doi: https://doi.org/10.1101/2021.07.19.21260782; this version posted July 28, 2021. The copyright holder for this preprint (which was not certified by peer review) is the author/funder, who has granted medRxiv a license to display the preprint in perpetuity.

It is made available under a CC-BY-NC-ND 4.0 International license .

Table 6A. Two-way fixed effects models with severe psychological distress (PHQ-4 scores 9 and above) regressed on vaccination status and perceived risk factors adjusting for state-by-wave fixed effects, April 2020 to June 2021 ( $\mathrm{N}=5,788$ )

\begin{tabular}{|c|c|c|c|c|c|c|}
\hline & \multicolumn{2}{|c|}{ Model 1} & \multicolumn{2}{|c|}{ Model 2} & \multicolumn{2}{|c|}{ Model 3} \\
\hline & Coef. & $95 \% \mathrm{CI}$ & Coef. & $95 \% \mathrm{CI}$ & Coef. & $95 \% \mathrm{CI}$ \\
\hline \multicolumn{7}{|l|}{$\begin{array}{l}\text { Received } \\
\text { Vaccination (ref: }\end{array}$} \\
\hline no) & $-0.09 * *$ & -0.14 to -0.03 & $-0.09 * *$ & -0.14 to -0.03 & -0.03 & -0.09 to 0.02 \\
\hline \multicolumn{7}{|c|}{ Received UI (ref: no) } \\
\hline Yes & & & 0.07 & -0.04 to 0.18 & 0.06 & -0.05 to 0.18 \\
\hline Unsure & & & -0.01 & -0.31 to 0.29 & -0.02 & -0.32 to 0.28 \\
\hline \multicolumn{7}{|c|}{ Received SNAP (ref: no) } \\
\hline Yes & & & 0.02 & -0.09 to 0.14 & 0.02 & -0.09 to 0.14 \\
\hline Unsure & & & $-0.20 *$ & -0.39 to -0.02 & $-0.20 *$ & -0.38 to -0.01 \\
\hline \multicolumn{7}{|c|}{ Currently working (ref: no) } \\
\hline Yes & & & 0.07 & -0.06 to 0.19 & 0.07 & -0.06 to 0.19 \\
\hline Risk of death & & & & & $0.03 * * *$ & 0.01 to 0.04 \\
\hline Risk of infection & & & & & $0.04 * * *$ & 0.03 to 0.04 \\
\hline Risk of Hospitalizat & & & & & $0.02 * * *$ & 0.01 to 0.03 \\
\hline $\begin{array}{l}\text { Individual fixed } \\
\text { effects }\end{array}$ & Yes & & Yes & & Yes & \\
\hline Wave fixed effects & Yes & & Yes & & Yes & \\
\hline $\begin{array}{l}\text { State } \times \text { wave fixed } \\
\text { effects }\end{array}$ & Yes & & Yes & & Yes & \\
\hline Constant & $2.35 * * *$ & 1.03 to 3.67 & $2.29 * * *$ & 0.96 to 3.63 & $2.07 * *$ & 0.74 to 3.41 \\
\hline N. of cases & 5,788 & & 5,788 & & 5,788 & \\
\hline
\end{tabular}

$* \mathrm{p}<0.05, * * \mathrm{p}<0.01, * * * \mathrm{p}<0.001$ 
medRxiv preprint doi: https://doi.org/10.1101/2021.07.19.21260782; this version posted July 28, 2021. The copyright holder for this preprint (which was not certified by peer review) is the author/funder, who has granted medRxiv a license to display the preprint in perpetuity.

It is made available under a CC-BY-NC-ND 4.0 International license .

\section{References}

1. UN. COVID-19 and the Need for Action on Mental Health.2020. Available from:

\section{https://unsdg.un.org/sites/default/files/2020-05/UN-Policy-Brief-COVID-19-and-mental-health.pdf.}

2. O'Connor RC, Wetherall K, Cleare S, McClelland H, Melson AJ, Niedzwiedz CL, et al. Mental health and well-being during the COVID-19 pandemic: longitudinal analyses of adults in the UK COVID-19 Mental Health \& Wellbeing study. The British Journal of Psychiatry. 2021;218(6):326-33.

3. Daly M, Robinson E. Psychological distress and adaptation to the COVID-19 crisis in the United States. Journal of psychiatric research. 2021;136:603-9.

4. Ettman CK, Abdalla SM, Cohen GH, Sampson L, Vivier PM, Galea S. Prevalence of depression symptoms in US adults before and during the COVID-19 pandemic. JAMA network open. 2020;3(9):e2019686-e.

5. Shevlin M, McBride O, Murphy J, Miller JG, Hartman TK, Levita L, et al. Anxiety, depression, traumatic stress and COVID-19-related anxiety in the UK general population during the COVID-19 pandemic. BJPsych Open. 2020;6(6).

6. Wu T, Jia X, Shi H, Niu J, Yin X, Xie J, et al. Prevalence of mental health problems during the COVID-19 pandemic: A systematic review and meta-analysis. Journal of affective disorders. 2020.

7. Purtle J. COVID-19 and mental health equity in the United States. Social psychiatry and psychiatric epidemiology. 2020;55(8):969-71.

8. Pancani L, Marinucci M, Aureli N, Riva P. Forced Social Isolation and Mental Health: A Study on 1,006 Italians Under COVID-19 Lockdown. Frontiers in Psychology. 2021;12:1540.

9. Hertz-Palmor N, Moore TM, Gothelf D, DiDomenico GE, Dekel I, Greenberg DM, et al. Association among income loss, financial strain and depressive symptoms during COVID-19: evidence from two longitudinal studies. Journal of affective disorders. 2021;291:1-8. 
medRxiv preprint doi: https://doi.org/10.1101/2021.07.19.21260782; this version posted July 28, 2021. The copyright holder for this preprint (which was not certified by peer review) is the author/funder, who has granted medRxiv a license to display the preprint in perpetuity.

It is made available under a CC-BY-NC-ND 4.0 International license .

10. Wilson JM, Lee J, Fitzgerald HN, Oosterhoff B, Sevi B, Shook NJ. Job insecurity and financial concern during the COVID-19 pandemic are associated with worse mental health. Journal of occupational and environmental medicine. 2020;62(9):686-91.

11. Witteveen $\mathrm{D}$, Velthorst E. Economic hardship and mental health complaints during COVID-19. Proceedings of the National Academy of Sciences. 2020;117(44):27277-84.

12. Donnelly R, Farina MP. How do state policies shape experiences of household income shocks and mental health during the COVID-19 pandemic? Social science \& medicine. 2021;269:113557.

13. Panchal N, Kamal R, Orgera K, Cox C, Garfield R, Hamel L, et al. The implications of COVID-19 for mental health and substance use. Kaiser family foundation. 2020;21.

14. Russell BS, Hutchison M, Tambling R, Tomkunas AJ, Horton AL. Initial challenges of caregiving during COVID-19: Caregiver burden, mental health, and the parent-child relationship. Child Psychiatry \& Human Development. 2020;51(5):671-82.

15. Wade M, Prime H, Johnson D, May SS, Jenkins JM, Browne DT. The disparate impact of COVID19 on the mental health of female and male caregivers. Social Science \& Medicine. 2021;275:113801.

16. Wu C, Qian Y, Wilkes R. Anti-Asian discrimination and the Asian-white mental health gap during COVID-19. Ethnic and Racial Studies. 2021;44(5):819-35.

17. Chae DH, Yip T, Martz CD, Chung K, Richeson JA, Hajat A, et al. Vicarious racism and vigilance during the CoViD-19 pandemic: mental health implications among Asian and Black Americans. Public Health Reports. 2021:00333549211018675.

18. Fang D, Thomsen MR, Nayga RM. The association between food insecurity and mental health during the COVID-19 pandemic. BMC public health. 2021;21(1):1-8.

19. Simon NM, Saxe GN, Marmar CR. Mental Health Disorders Related to COVID-19-Related Deaths. JAMA. 2020;324(15):1493-4. 
medRxiv preprint doi: https://doi.org/10.1101/2021.07.19.21260782; this version posted July 28, 2021. The copyright holder for this preprint (which was not certified by peer review) is the author/funder, who has granted medRxiv a license to display the preprint in perpetuity.

It is made available under a CC-BY-NC-ND 4.0 International license .

20. Joaquim RM, Pinto ALCB, Guatimosim RF, de Paula JJ, Souza Costa D, Diaz AP, et al.

Bereavement and psychological distress during COVID-19 pandemics: The impact of death experience on mental health. Current Research in Behavioral Sciences. 2021;2:100019.

21. Robinson E, Daly M. Explaining the rise and fall of psychological distress during the COVID-19 crisis in the United States: Longitudinal evidence from the Understanding America Study. British journal of health psychology. 2021;26(2):570-87.

22. COVID-19 Vaccinations in the United States. Centers for Disease Control and Prevention [Internet]. 2021 July 4 2021. Available from: https://covid.cdc.gov/covid-data-tracker/\#vaccinations.

23. See How Vaccinations Are Going in Your County and StateJuly 4 2021. Available from: https://www.nytimes.com/interactive/2020/us/covid-19-vaccine-doses.html.

24. Liz Hamel, Lunna Lopes, Audrey Kearney, Grace Sparks, Mellisha Stokes, and Mollyann Brodie. KFF COVID-19 Vaccine Monitor: June 20212021 Jun 30, 2021. Available from: https://www.kff.org/coronavirus-covid-19/poll-finding/kff-covid-19-vaccine-monitor-june-2021/.

25. Willis DE, Andersen JA, Bryant-Moore K, Selig JP, Long CR, Felix HC, et al. COVID-19 vaccine hesitancy: Race/ethnicity, trust, and fear. Clinical and Translational Science.

2021:doi.org/10.1111/cts.13077.

26. Julia Raifman AS, and David Michaels. Something to celebrate: delivering vaccines to essential workers. STAT [Internet]. 2021 July 5, 2021. Available from:

https://www.statnews.com/2021/07/01/essential-workers-getting-vaccinated-something-tocelebrate/?utm content=buffer1810c\&utm medium=social\&utm source=twitter\&utm campaign=twitt er organic.

27. Understanding Coronavirus in America Survey. [Internet]. Center for Economic and Social Research (CESR). [cited July 1, 2021.]. Available from: https://uasdata.usc.edu/index.php. 
medRxiv preprint doi: https://doi.org/10.1101/2021.07.19.21260782; this version posted July 28, 2021. The copyright holder for this preprint (which was not certified by peer review) is the author/funder, who has granted medRxiv a license to display the preprint in perpetuity.

It is made available under a CC-BY-NC-ND 4.0 International license .

28. Kroenke K, Spitzer RL, Williams JB, Löwe B. An ultra-brief screening scale for anxiety and depression: the PHQ-4. Psychosomatics. 2009;50(6):613-21.

29. Löwe B, Wahl I, Rose M, Spitzer C, Glaesmer H, Wingenfeld K, et al. A 4-item measure of depression and anxiety: validation and standardization of the Patient Health Questionnaire-4 (PHQ-4) in the general population. Journal of affective disorders. 2010;122(1-2):86-95.

30. Venkataramani AS, Bair EF, O’Brien RL, Tsai AC. Association Between Automotive Assembly Plant Closures and Opioid Overdose Mortality in the United States: A Difference-in-Differences Analysis. JAMA Internal Medicine. 2020;180(2):254-62.

31. Raifman J, Bor J, Venkataramani A. Association Between Receipt of Unemployment Insurance and Food Insecurity Among People Who Lost Employment During the COVID-19 Pandemic in the United States. JAMA Network Open. 2021;4(1):e2035884-e.

32. Clarke D, Schythe K. Implementing the panel event study2020. Available from: http://www.damianclarke.net/research/papers/panelEvent.pdf.

33. CSUSB. Report to the Nation: Anti-Asian Prejudice \& Hate Crime. San Bernardino, CA Center for the Study of Hate \& Extremism.; [updated Accessed: July 11, 2021. Available from:

https://www.csusb.edu/sites/default/files/Report\%20to\%20the\%20Nation\%20-\%20AntiAsian\%20Hate\%202020\%20Final\%20Draft\%20\%20As\%20of\%20Apr\%2030\%202021\%206\%20PM\%20corrected.pdf.

34. Goodman-Bacon A, Marcus J. Using difference-in-differences to identify causal effects of COVID19 policies. 2020.

35. Murphy J, Vallières F, Bentall RP, Shevlin M, McBride O, Hartman TK, et al. Psychological characteristics associated with COVID-19 vaccine hesitancy and resistance in Ireland and the United Kingdom. Nature communications. 2021;12(1):1-15. 